\title{
SYNTHESIS AND CHARACTERIZATION OF BIS(PHOSPHINOMETHYL)- MAGNESIUM COMPOUNDS - STRUCTURE OF $\left[\mathrm{Mg}\left(\mathrm{CH}_{2} \mathrm{PPh}_{2}\right)_{2}\right.$ (tmeda) $] \cdot 2 \mathrm{Et}_{2} \mathrm{O}$
}

\author{
Tobias Rüffer, Clemens Bruhn and Dirk Steinborn* \\ Institut fur Anorganische Chemie, Martin-Luther-Universität Halle-Wittenberg, \\ Kurt-Mothes-Strasse 2, 06120 Halle, Germany
}

Tmeda adducts of phosphinomethyllithium compounds $\left[\left\{\mathrm{LiCH}_{2} \mathrm{PR}_{2} \text { (tmeda) }\right\}_{2}\right](\mathrm{R}=\mathrm{Me}, \mathrm{Ph}$; tmeda $=$ $N, N, N^{*}, N^{\prime}$-tetramethy lethylenediamine) react with $\mathrm{MgCl}_{2}$ in $\mathrm{THF} / \mathrm{Et}_{2} \mathrm{O}$ yielding $\mathrm{Mg}\left(\mathrm{CH}_{2} \mathrm{PMe}_{2}\right)_{2} \cdot 2 \mathrm{LiCl} \mathbf{1 a}$ and $\left[\mathrm{Mg}\left(\mathrm{CH}_{2} \mathrm{PPh}_{2}\right)_{2}\right.$ (tmeda)] $2 \mathrm{Et}_{2} \mathrm{O} \mathbf{1 b}$, respectively. The two $\mathrm{Et}_{2} \mathrm{O}$ molecules in $\mathbf{1 b}$ are rapidly lost in vacuo yielding $\left[\mathrm{Mg}\left(\mathrm{CH}_{2} \mathrm{PPh}_{2}\right)_{2}\right.$ (tmeda)] $1 \mathbf{b}^{\circ}$. The identities of compounds 1 were confirmed by microanalysis and NMR spectroscopy $\left({ }^{1} \mathrm{H},{ }^{13} \mathrm{C},{ }^{31} \mathrm{P}\right)$. As shown by X-ray diffraction analysis, compound $\mathbf{1 b}$ crystallizes as a monomer with crystallographically imposed $C_{2}$ symmetry. The magnesium environment is distorted tetrahedral with a primary donor set made up by two nitrogen atoms of the tmeda ligand and two carbon atoms of the $\eta^{1}$-coordinated $\mathrm{Ph}_{2} \mathrm{PCH}_{2}$ ligands. The $\mathrm{P}-\mathrm{CH}_{2}$ bonds are shortened due to stabilization of the carbanionoid $\mathrm{C}$ atom by phosphorus. There are no unusual short interactions between the magnesium complex and the $\mathrm{Et}_{2} \mathrm{O}$ molecules of crystallization.

\section{INTRODUCTION}

Main-group organometallics of the type $\mathrm{L}_{x} \mathrm{M}-\mathrm{CH}_{2} \mathrm{YR} n(\mathrm{Y}=$ heteroatom, $\mathrm{R}==$ alkyl, aryl, $\mathrm{H}, \mathrm{L}=$ ligand) with Lewis-basic heteroatomic centers $\left(\mathrm{YR}_{n}=\mathrm{NR}_{2}, \mathrm{PR}_{2}, \mathrm{OR}, \mathrm{SR}, \mathrm{F}, \mathrm{Cl}, \ldots\right)$ exhibit a great diversity of structures (e.g. $\eta^{2}-\left(\kappa^{2} C, Y-\right)$ coordination). Because of the Lewis-basic heteroatoms they are highly reactive in many cases, opening the possibility of entirely new reactions. Thus, carbenoid reactivity of halo- and oxymethyl lithium and Grignard compounds has been known for more than 30 years ago $^{12}$ but that of the thiomethyl compound [ $\mathrm{LiCH}_{2} \mathrm{SPh}$ (pmdta)] (pmdta $=N, N, N^{\prime}, N^{\prime \prime}, N^{\prime \prime}$-pentamethyldiethy lenetriamine) very recently. ${ }^{3}$

Phosphinomethyl lithium compounds $\mathrm{LiCH}_{2} \mathrm{PR}_{2}$ are well-known and proved to be typical bifunctional ambident compounds. ${ }^{4-7}$ Grignard compounds $\mathrm{Mg}\left(\mathrm{CH}_{2} \mathrm{PR}_{2}\right) \mathrm{X}^{8}$ and $\mathrm{Mg}\left\{\mathrm{CH}_{2} \mathrm{P}(\mathrm{O}) \mathrm{R}_{2}\right\} \mathrm{X}^{9}{ }^{10}$ were prepared in solution and $\mathrm{Mg}\left\{\mathrm{CH}_{2} \mathrm{P}\left(\mathrm{NSiMe}_{3}\right) \mathrm{Me}_{2}\right\} \mathrm{X}^{11}$ was even isolated as solid. It was also shown, that phosphorus ylides and double ylides can coordinate to magnesium. ${ }^{12}$ Furthermore, the tetrakis $(P, P$ dimethylphosphinomethyl)magnesate complex $[\mathrm{Li}(\text { tmeda })]_{2}\left[\mathrm{Mg}\left(\mathrm{CH}_{2} \mathrm{PMe}_{2}\right)_{4}\right]$ has been prepared ${ }^{13}$ The only compounds of the type $\left[\mathrm{Mg}\left(\mathrm{CH}_{2} \mathrm{YR}_{n}\right)_{2}\right]$ with Lewis-basic heteroatoms isolated so far are those with $\mathrm{YR}_{n}=$ $\mathrm{SPh}, \mathrm{SMe}{ }^{14}$ Carbenoids of the type $\mathrm{Mg}(\mathrm{CHRX})_{2}(\mathrm{X}=\mathrm{CI}, \mathrm{Br}, \mathrm{I} ; \mathrm{R}=$ alkyl) were characterized by NMR spectroscopy. ${ }^{15}$

Here we report synthesis and characterization of bis(phosphinomethyl)magnesium compounds as well as the structure of $\operatorname{bis}(P, P$-diphenylphosphinomethyl $)\left(N, N, N^{\prime}, N^{\prime}\right.$-tetramethylethylenediamine)magnesium-bis(diethyl ether) solvate.

\section{MATERIALS AND METHODS}

All reactions and manipulations were carnied out under purified argon using standard Schlenk tcchniques and a glove box from $\mathrm{Fa}$. MB Braun. $n$-Hexane, tmeda and $\left[\mathrm{D}_{8}\right] \mathrm{THF}$ were dried with LiAll $\mathrm{L}_{4}$. THF and diethyl ether were distilled from sodium benzophenone ketyl. NMR spectra were recorded on a Gemini 200 spectrometer (Varian) using the protio impurities and ${ }^{13} \mathrm{C}$ resonances of the deuterated solvents as references for ${ }^{1} \mathrm{H}$ and ${ }^{13} \mathrm{C}$ NMR spectroscopy, respectively. $\delta\left({ }^{31} \mathrm{P}\right)$ is relative to external $\mathrm{H}_{3} \mathrm{PO}_{4}(85 \%)$. Microanalyses (C, $\mathrm{H}, \mathrm{N})$ were obtained from the microanalytical laboratory of the Department of Chemistry. Compounds $\left[\left\{\mathrm{LiCH}_{2} \mathrm{PR}_{2} \text { (tmeda) }\right\}_{2}\right](\mathrm{R}=\mathrm{Me}, \mathrm{Ph})$ were prepared according to the literature ${ }^{16}{ }^{17} \mathrm{MgCl}_{2}$ was commercially available (Merck).

Synthesis of $\mathrm{Mg}\left(\mathrm{CH}_{2} \mathrm{PMe}_{2}\right)_{2} \cdot 2 \mathrm{LiCl} 1 \mathrm{a}$

At $-78{ }^{\circ} \mathrm{C}$, [\{ $\left\{\mathrm{LiCH}_{2} \mathrm{PMe}_{2} \text { (tmeda) }\right\}_{2}$ ] $(892 \mathrm{mg}, 2.25 \mathrm{mmol})$ and $\mathrm{MgCl}_{2}(214 \mathrm{mg}, 2.25 \mathrm{mmol})$ were dissolved in THF (10 ml) and stirred for $1 \mathrm{~h}$ yielding a cloudy solution. After stirring overnight at room temperature a clear solution was obtained. Half of the THF was removed in vacuo and diethyl ether $(50 \mathrm{ml})$ was added. The colorless precipitate of $1 \mathrm{a}$ was filtered, washed with hexane and dried in vacuo (Yield: $470 \mathrm{mg}, 81 \%$ ).

C, $27.80 ; \mathrm{H}, 6.22$. Found: C, 26.91; H, 5.98. ${ }^{1} \mathrm{H}$ NMR (200 MHz, [D $]$ THF): $\delta-0.60\left(\mathrm{~d}, 4 \mathrm{H},{ }^{2} J(\mathrm{P}, \mathrm{H})=2.15\right.$ $\left.\mathrm{Hz}, \mathrm{C} H_{2}\right), 0.90 \mathrm{ppm}\left(\mathrm{s}, 12 \mathrm{H}, \mathrm{CH} H_{3}\right) .{ }^{13} \mathrm{C} N M R\left(50 \mathrm{MHz},\left[\mathrm{D}_{8}\right] \mathrm{THF}\right): \delta 10.3\left(\mathrm{~d},{ }^{1} J(\mathrm{P}, \mathrm{C})=28.0 \mathrm{~Hz}, \mathrm{CH}_{2}\right), 22.6$ ppm (s, $\left.\mathrm{CH}_{3}\right)$. ${ }^{31} \mathrm{P}$ NMR $\left(81 \mathrm{MHz},\left[\mathrm{D}_{8}\right] \mathrm{THF}\right): \delta-38.7 \mathrm{ppm}$.

\section{Synthesis of $\left[\mathrm{Mg}\left(\mathrm{CH}_{2} \mathrm{PPh}_{2}\right)_{2}\right.$ (tmeda) $2 \mathrm{Et}_{2} \mathrm{O} \mathbf{1 b}$ and $\left[\mathrm{Mg}\left(\mathrm{CH}_{2} \mathrm{PPh}_{2}\right)_{2}(\right.$ tmeda $\left.)\right] \mathbf{1 b}^{\circ}$}

As described for 1a, a solution of $\left[\mathrm{Mg}\left(\mathrm{CH}_{2} \mathrm{PPh}_{2}\right)_{2}\right.$ (tmeda) $]$ in THF was prepared from [\{ $\mathrm{LiCH}_{2} \mathrm{PPh}_{2}$ (tmeda) $\left.\}_{2}\right](1.451 \mathrm{~g}, 2.25 \mathrm{mmol})$ and $\mathrm{MgCl},(214 \mathrm{mg}, 2.25 \mathrm{mmol})$. After removing the half of the THF in vacuo, diethyl ether $(1-2 \mathrm{ml})$ was added. At $-40^{\circ} \mathrm{C}, 1 \mathbf{b}$ crystallizes in well shaped colorless 
crystals that were suitable for X-ray crystallography. The crystals were filtered, washed with hexane and dried in vacuo yielding $1 \mathbf{b}^{\prime}$ (Yield: $1.10 \mathrm{~g}, 91 \%$ ).

1b': C, 71.32; H, 7.48; N, 5.20. Found: C, 69.78; H, 7.28; N 5.05. ${ }^{1} \mathrm{H}$ NMR $\left(200 \mathrm{MHz},\left[\mathrm{D}_{8}\right] \mathrm{THF}\right): \delta 0.02(\mathrm{~s}$, $\left.4 \mathrm{H}, \mathrm{CH}_{2} \mathrm{P}\right), 2.12\left(\mathrm{~s}, 12 \mathrm{H}, \mathrm{N}\left(\mathrm{CH}_{3}\right)_{2}\right), 2.36\left(\mathrm{~s}, 4 \mathrm{H}, \mathrm{CH}_{2} \mathrm{~N}\right), 7.09-7.56 \mathrm{ppm}\left(\mathrm{m}, 20 \mathrm{H}, \mathrm{C}_{6} \mathrm{H}_{5}\right) .{ }^{13} \mathrm{C} \mathrm{NMR}(50$ MHz, [D $\mathrm{D}_{8}$ THF): $\delta 3.1\left(\mathrm{~d},{ }^{1} J(\mathrm{P}, \mathrm{C})=40.0 \mathrm{~Hz}, \mathrm{CH}_{2} \mathrm{P}\right), 46.3\left(\mathrm{~s}, \mathrm{~N}\left(\mathrm{CH}_{3}\right)_{2}\right), 58.4\left(\mathrm{~s}, \mathrm{CH}_{2} \mathrm{~N}\right), 126.9(\mathrm{~s}, p-\mathrm{C}), 128.1$ $\left(\mathrm{d},{ }^{3} J(\mathrm{P}, \mathrm{C})=5.4 \mathrm{~Hz}, m-\mathrm{C}\right), 132.6\left(\mathrm{~d}{ }^{2} J(\mathrm{P}, \mathrm{C})=17.7 \mathrm{~Hz}, o-\mathrm{C}\right)$ [Assignment of $o$ - and $m$-C based on lit. ${ }^{17}$ ], $150.2 \mathrm{ppm}\left(\mathrm{d},{ }^{1}, J(\mathrm{P}, \mathrm{C})=20.0 \mathrm{~Hz}, i-\mathrm{C}\right) .{ }^{3 \mathrm{l}} \mathrm{P}$ NMR $\left(81 \mathrm{MHz},\left[\mathrm{D}_{8}\right] \mathrm{THF}\right): \delta 0.4 \mathrm{ppm}$.

$X$-ray structure determination of $1 \mathbf{b}$

X-ray measurement of a suitable single crystal of $\mathbf{1 b}$ was performed on a Stoe IPDS diffractometer with $\operatorname{Mo} K_{\alpha}$ radiation $(\lambda=0.71073 \Delta$, graphite monochromator). The structure was solved bv direct methods $\left(\right.$ SHELXS-86 ${ }^{18}$ ) and refined using full-matrix least-squares procedures on $F^{2}$ (SHELXL-93 ${ }^{10}$ ). Non-hydrogen atoms were refined with anisotropic displacement parameters. Hydrogen atoms at CI were found in the difference Fourier map and refined isotropically. The other $\mathrm{H}$ atoms were placed in calculated positions according to the "riding model" with fixed (methyl $\mathrm{H}$ atoms) and freely refined displacement parameters, respectively. Crystal data, details of data collection, structure solution and refinement are summarized in Table 1.

Table 1. Crystal data collection and processing parameters for compiex $\mathbf{1 b}$.

\begin{tabular}{llll}
\hline Formula & $\mathrm{C}_{40} \mathrm{H}_{60} \mathrm{MgN}_{2} \mathrm{O}_{25}$ & Formula weight & 687.15 \\
Crystal size, mm & $0.20 \times 0.20 \times 0.10$ & Temperature, $\mathrm{K}$ & $220(2)$ \\
Crystal system & monoclinic & Space group & $A 2 / n$ \\
$a, \AA$ & $20.478(5)$ & $b, \AA$ & $8.788(6)$ \\
$c, \AA$ & $23.234(7)$ & $\beta,{ }^{\circ}$ & $98.54(3)$ \\
$V, \AA^{3}$ & $4135(3)$ & $Z$ & 4 \\
$D_{\text {calcd }} \mathrm{g} \mathrm{cm}^{-3}$ & 1.104 & $\mu\left(\mathrm{Mo} K_{\alpha}\right), \mathrm{cm}^{-1}$ & 1.53 \\
$F(000)$ & 1488 & Scan range, & $2.01<\theta<23.50$ \\
Reflns measured & 6659 & Reflns unique, $R_{\text {int }}$ & $2989,0.1208$ \\
Reflns with $I>2 \sigma(I)$ & 1874 & Parameters refined & 233 \\
Goodness-of-fit on $F^{2}$ & 0.962 & $\rho$ (max/min), e $\AA^{-3}$ & $0.419 /-0.535$ \\
$R 1, w R 2[I>2 \sigma(I)]$ & $0.0620,0.1574$ & $R 1, w R 2$ (all data) & $0.1006,0.1776$ \\
Deposition number ${ }^{19}$ & $C C D C-159772$ & &
\end{tabular}

\section{RESULTS AND DISCUSSION}

$N, N, N^{\prime}, N^{\prime}$-Tetramethylethylenediamine (tmeda) adducts of phosphinomethyllithium compounds $\left[\left\{\mathrm{LiCH}_{2} \mathrm{PR}_{2}(\mathrm{tmeda})\right\}_{2}\right](\mathrm{R}=\mathrm{Me}, \mathrm{Ph})$ react with stoichiometric amounts of magnesium chloride in tetrahydrofuran to give bis(phosphinomethyl)magnesium compounds 1 (Scheme 1). In the case of the $P, P$ dimethylphosphinomethyl derivative, the addition of diethyl ether to the reaction solution leads to an adduct with lithium chloride $\mathrm{Mg}\left(\mathrm{CH}_{2} \mathrm{PMe}_{2}\right)_{2} 2 \mathrm{LiCl} \mathrm{1 \textrm {a }}$, that does not contain tmeda. In the case of the $P, P$ diphenylphosphinomethyl derivative, the addition of diethyl ether to the reaction solution results in the formation of the tmeda complex $\left[\mathrm{Mg}\left(\mathrm{CH}_{2} \mathrm{PPh}_{2}\right)_{2}(\mathrm{tmeda})\right] 2 \mathrm{Et}_{2} \mathrm{O}$ lb. The two $\mathrm{Et}_{2} \mathrm{O}$ molecules of crystallization are rapidly lost in vacuo yielding $\left[\mathrm{Mg}\left(\mathrm{CH}_{2} \mathrm{PPh}_{2}\right)_{2}\right.$ (tmeda)] $\mathbf{1 b}^{*}$.

Compounds 1 were isolated as colorless powders $\left(\mathbf{1 a}, \mathbf{1 b}^{\circ}\right)$ or crystals $(\mathbf{1 b})$ which are very sensitive against air and moisture. The identities of compounds 1 were confirmed by microanalysis and NMR spectroscopy $\left({ }^{1} \mathrm{H},{ }^{13} \mathrm{C},{ }^{31} \mathrm{P}\right)$ and by $\mathrm{X}$-ray crystallography (1b). The methylene protons of $1 \mathbf{b b}^{\prime}$ are shifted downfield by 0.39 ppm with respect to its lithium analogue $\left(0.02 \mathrm{ppm}\right.$ in $1 \mathbf{b}^{\prime}$ versus $-0.37 \mathrm{ppm}$ in $\left.\left[\left\{\mathrm{LiCH}_{2} \mathrm{PPh}_{2}(\mathrm{tmeda})\right\}_{2}\right]^{17}\right)$. The ${ }^{13} \mathrm{C}$ resonances of the methylene carbon atoms (AA $\mathrm{X}$ or - taking into account the isotopic shift of ${ }^{13} \mathrm{C}$ - $\mathrm{ABX}$ spin systems; $\mathrm{A}, \mathrm{B}={ }^{31} \mathrm{P}, \mathrm{X}={ }^{13} \mathrm{C}$ ) are split into a doublet. This appearance points to weakly coupled systems $\left(J_{\mathrm{AA}}=0 \mathrm{~Hz}, J_{\mathrm{A}^{\prime} \mathrm{X}}=0 \mathrm{~Hz}\right)$ that were analyzed as first order spectra $\left({ }^{1} J(\mathrm{P}, \mathrm{C})=28.0 \mathrm{~Hz} 1 \mathrm{a},{ }^{1} J(\mathrm{P}, \mathrm{C})=\right.$ $\left.20.0 \mathrm{~Hz} \mathbf{l b}^{\prime}\right)$. 


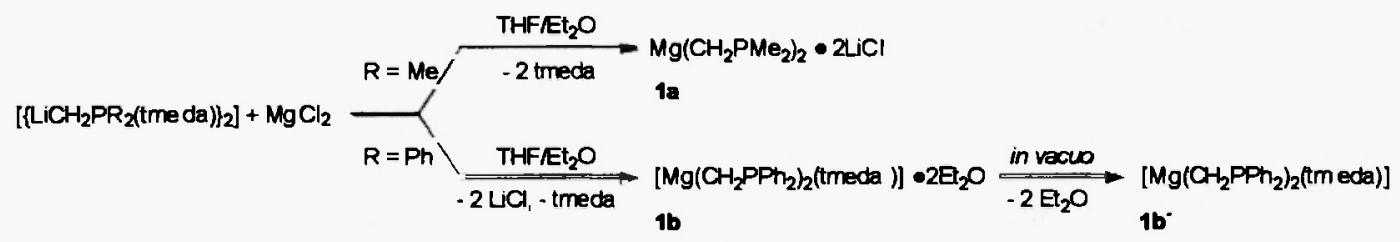

Scheme 1

Figure 1. Molecular structure and numbering scheme of $\left[\mathrm{Mg}\left(\mathrm{CH}_{2} \mathrm{PPh}_{2}\right)_{2}(\mathrm{tmeda})\right] 2 \mathrm{Et}_{2} \mathrm{O}$ 1b. Ellipsoids are drawn at $30 \%$ probability. $\mathrm{Et}_{2} \mathrm{O}$ molecules are omitted.

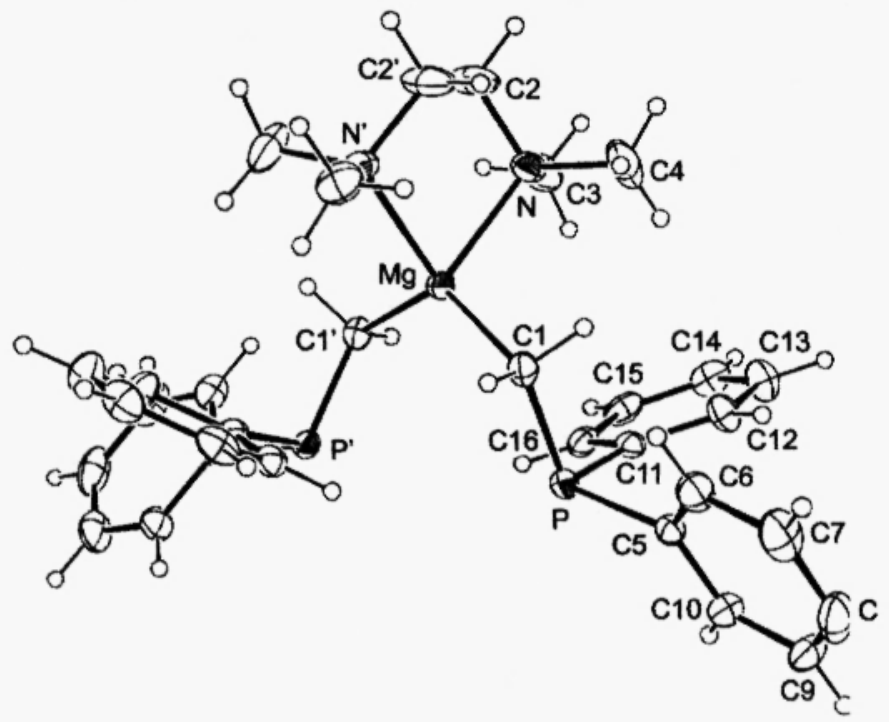

The molecular structure of complex $\mathbf{1 b}$ along with the atom numbering scheme is shown in Figure 1. Selected bond lengths and angles are listed in Table 2 . The structure consists of the monomeric magnesium complex and two diethyl ether molecules without any unusual intermolecular interaction between them (shortest intermolecular distance between non-hydrogen atoms: $>3.5 \AA$ ). The magnesium complex exhibits crystallographically imposed $C_{2}$ symmetry.

Table 2. Selected bond distances (in $\AA$ ) and bond angles (in ${ }^{\circ}$ ) for $1 \mathbf{b}$

\begin{tabular}{|c|c|c|c|}
\hline $\mathrm{Mg}-\mathrm{Cl}$ & $2.171(4)$ & $\mathrm{P}-\mathrm{C5}$ & $1.844(4)$ \\
\hline$M \bar{g}-\mathrm{N}$ & $2.226(4)$ & $\mathrm{P}-\mathrm{Cll}$ & $1.839(4)$ \\
\hline $\mathrm{P}-\mathrm{Cl}$ & $1.792(4)$ & & \\
\hline $\mathrm{Cl}-\mathrm{Mg}-\mathrm{Cl}^{\prime a)}$ & $130.0(2)$ & $\mathrm{Mg}-\mathrm{Cl}-\mathrm{P}$ & $114.8(2)$ \\
\hline $\mathrm{N}-\mathrm{Mg}-\mathrm{N}^{\prime}$ & $82.3(2)$ & $\mathrm{Cl}-\mathrm{P}-\mathrm{C} 5$ & $108.1(2)$ \\
\hline $\mathrm{Cl}-\mathrm{Mg}-\mathrm{N}$ & $107.8(2)$ & $\mathrm{Cl}-\mathrm{P}-\mathrm{Cll}$ & $101.1(2)$ \\
\hline $\mathrm{Cl}-\mathrm{Mg}-\mathrm{N}^{\prime}$ & $109.3(2)$ & $\mathrm{C} 5-\mathrm{P}-\mathrm{C} 11$ & $99.0(2)$ \\
\hline
\end{tabular}

a) Symmetry transformation for equivalent atoms: : $-x+1 / 2, y,-z+1 / 2 \_$

Magnesium adopts a tetrahedral coordination with remarkable deviations from the ideal geometry. Due to the small "bite" of the tmeda ligand the angle $\mathrm{N}-\mathrm{Mg}-\mathrm{N}$ amounts to $82.3(2)^{\circ}$ as in other magnesium tmeda complexes (median $82.1^{\circ}$; lower/upper quartile $80.7 / 83.0^{\circ}$ for 25 data points ${ }^{20}$ ). On the other hand, the angle $\mathrm{C}-\mathrm{Mg}-\mathrm{C}$ is significantly widened up $\left(130.0(2)^{\circ}\right)$. The $\mathrm{C}-\mathrm{Mg}-\mathrm{N}$ angles are close to the ideal tetrahedral angle $\left(107.8(2)^{\circ}, 109.3(2)^{\circ}\right)$. 
The phosphinomethyl ligands are $\eta^{1}$ - ( $\kappa C$-) bound. The $\mathrm{Mg}-\mathrm{C}$ bond lengths (2.171(4) $\AA$ ) are in the range of those in complexes $\left[\mathrm{MgR}_{2}\right.$ (tmeda)] $\left(\mathrm{R}=\mathrm{Me}, \mathrm{Et}\right.$, sec-Bu) $(2.137(6) 21181(3) \AA)^{21-23}$ and in $\left[\mathrm{Mg}\left(\mathrm{CH}_{2} \mathrm{SR}\right)_{2}(\mathrm{thf})_{3}\right](\mathrm{R}=\mathrm{Me}, \mathrm{Ph})(2.168(6)-2.196(3) \AA) .{ }^{14}$ The bond length between the trivalent phosphorus and the methylene group (1.792(4) $\AA$ ) is in the range of those in quarternary phosphonium compounds (median 1.802 $\AA$; lower/upper quartile $1.790 / 1.812 \AA^{27}$ ). The $\mathrm{P}-\mathrm{CH}_{2}$ bond is even significantly shorter than the $\mathrm{P}-\mathrm{C}_{\mathrm{Ph}}$ distances $\left(1.839(4)\right.$ and $1.844(4) \AA$ ) in spite of the smaller covalent radii of $\mathrm{sp}^{2}$ hybridized carbons in comparison with sp ${ }^{3}$ hybridized ones. Expected values (median; lower/upper quartile in parantheses) for $\mathrm{P}-\mathrm{C}_{\mathrm{sp} 3}$ and $\mathrm{P}-\mathrm{C}_{\text {aryl }}$ in trivalent phosphorus compounds are $1.857 \AA(1.840 / 1.870 \AA)$ and $1.837 \AA(1.830 / 1.844 \AA)$, respectively. ${ }^{24}$ The same observation was made in phosphinomethyl lithium compounds ${ }^{16,17,25}$ and it seems likely, that this in part arises from a stabilizing influence on the carbanionoid center of phosphorus by polarisation. ${ }^{26}$ The angles around phosphorus are between $99.0(2)$ and $108.1(2)^{\circ}$.

From the structure of complex $\mathbf{1 b}$ it is evident that phosphorus atoms of the $P, P$-diphenylphosphinomethyl ligands are not coordinated to magnesium. The structure of complex $1 \mathbf{a}$ is unknown yet. Formation of a tmeda-free complex may indicate that the stronger Lewis-basic phosphorus atoms of the $\mathrm{Me}_{2} \mathrm{PCH}_{2}$ ligands are coordinated to magnesium or lithium.

\section{ACKNOWLEDGMENTS}

We gratefully acknowledge financial support by the Deutsche Forschungsgemeinschaft and the Fonds der Chemischen Industrie as well as the company Merck (Darmstadt) for gifts of chemicals.

\section{REFERENCES}

1. G. Köbrich, Angew. Chem. 1972, 84, 557.

2. J. Villieras, Organometal. Chem. Rev. A 1971, 7, 81 .

3. T. Rüffer, C. Bruhn, A. H. Maulitz, D. Ströhl, D. Steinborn, Organometallics 2000, 19, 2829.

4. D. J. Peterson, Organometal. Chem. Rev. A 1972, 7, 295.

5. A. Krief, Tetrahedron 1980, 36, 2531 .

6. H.-P. Abicht, K. Issleib, Z. Chem. 1981, 21, 341.

7. H. H. Karsch, A. Appelt, Phosphorus Sulfur 1983, 18, 287

8. H. F. Luecke, R. G. Bergman, J. Am. Chem. Soc. 1997, 119, 11538.

9. P. O'Brien, S. Warren, Tetrahedron Letters 1995, 36, 2681.

10. T. Kawashima, Y. Yuzawa, N. Inamoto, Phosphorus Sulfur Silicon Relat. Elem. 1991, 60, 21

11. A. Müller, M. Krieger, B. Neumüller, K. Dehnıcke, J. Magull, Z. Anorg. Allg. Chem. 1997, 623, 1081

12. H. Schmidbaur, H.-J. Fuller, Chem. Ber. 1977, 110, 3528. H. Schmidbaur, G. Muller, Monatsh. Chem. $1980,111,1233$.

13. H. H. Karsch, V. Graf, M. Reisky, Phosphorus Sulfur Silicon Relat. Elem. 1999, 144-146, 553.

14. D. Steinborn, T. Ruffer, C. Bruhn, F. W. Heinemann, Polyhedron 1998, 17, 3275.

15. V. Schulze, R. Löwe, S. Fau, R. W. Hoffmann, J. Chem. Soc., Perkin Trans. II 1998, 463.

16. L. T. Byrne, L. M. Engelhardt, G. E. Jacobsen, W.-P. Leung, R. I. Papasergio, C. L. Raston, B. W. Skelton, P. Twiss, A. H. White, J. Chem. Soc., Dalton Trans. 1989, 105.

17. G. Fraenkel, W. R. Winchester, P. G. Williard, Organometallics 1989, 8, 2308. S. Blaurock, O. Kühl, E. Hey-Hawkins, Organometallics 1997, 16, 807.

18. G. M. Sheldrick, SHELXS-86, SHEIXL-93, Programs for Crystal Structure Determination, University of Göttingen, Göttingen 1986, 1993.

19. Copies of data deposited at the CCDC may be obtained free of charge from The Director, CCDC, 12 Union Road, Cambridge CB2 1EZ, England (Facsimile: 44-1223-336033 or e-mail: deposit@ccdc.cam. ac.uk).

20. Cambridge Crystallographic Database (CSD), Cambridge Crystallographic Data Centre, University Chemical Laboratory, Cambridge (England).

21. T. Greiser, J. Kopf, D. Thoennes, E. Weiss, J. Organometal. Chem. 1980, 191, 1 .

22. H. Viebrock. E. Weiss, J. Organometal. Chem. 1994, 464, 121.

23. H. D. R. Bamett, W. Clegg, R. E. Mulvey, P. A. O'Neil, D. Reed, J. Organometal. Chem. 1996, 510, 297.

24. F. H. Allen, O. Kennard, D. G. Watson, L. Brammer, A. G. Orpen, R. Taylor, J. Chem. Soc., Perkin Trans II 1987, S1.

25. D. Steinborn, O. Neumann, H. Weichmann, F. W. Heinemann, J.-P. Wagner, Polyhedron 1998, 17, 351.

26. P. v. R. Schleyer, T. Clark, A. J. Kos, G. W. Spitznagel, C. Rohde, D. Arad, K. N. Houk, N. G. Rondan, J. Am. Chem. Soc. 1984, 106, 6467.

\section{Received: May 23, 2001 - Accepted: May 28, 2001 - Accepted in pubiishable format: May 30, 2001}

